\title{
TRADITIONAL AND REGIONAL FOOD PRODUCTS AS THE EXAMPLE OF MARKETING INNOVATIONS IN THE PETROL STATION SECTOR IN POLAND
}

\author{
Jan MIKOŁAJCZYK ${ }^{1 *}$, Tomasz ZAWADZKI ${ }^{2}$ \\ ${ }^{1}$ Poznan University of Economics and Business; j.mkolajczyk@ue.poznan.pl, ORCID 0000-0002-6767-4822 \\ ${ }^{2}$ Poznan University of Economics and Business; tomasz.zawadzki@ue.poznan.pl, \\ ORCID 0000-0001-9368-2845 \\ * Correspondence author
}

Purpose: The principal aim of the article is to present changes in the accessibility of regional products understood as introducing them into trade formats in which they have not previously been present. The article will also present the characteristics of the petrol station sector in Poland.

Design/methodology/approach: The article will present the results of own research in terms of perception and assessment of marketing innovations by station customers. The study was carried out using the CAWI internet interview technique on a nationwide, representative sample of adult Poles.

Findings: The research shows that Poles are eager to buy regional products and look for them in places where they have never been available before (petrol stations).

Practical implications: This article concerns the case study of PKN ORLEN petrol station network. It can be assumed that the remaining operators of the station networks will introduce regional products to the offer shortly as the regional goods are being chosen increasingly and desired by customers of petrol stations in Poland.

Originality/value: The article deals with the problem of selling products at petrol stations, i.e. in a trade format that is not sufficiently described in the literature. The authors see a research gap in this field.

Keywords: Regional food products, Marketing, Innovations, Petrol stations.

Category of the paper: Research paper, case study.

\section{Introduction}

Agriculture and the food industry have occupied a unique place in the Polish economy over many years. Agriculture sector is responsible for a total of around 7\% of GDP (http://promocjazywnosci.pl/index.html) and $15 \%$ of employment (GUS, Rocznik 
Statystyczny, 2018). The food industry receives public administration support at the national and EU level as well as from numerous non-governmental organizations. One of the important forms of the support obtained is the institutional promotion of food. This promotion can be deemed as the involvement of public institutions in the promotion of a brand or product category taking various forms, for example including quality certificate awards. The awarding of "regional marks" increases the competitiveness of products and it is an important element which influences customer behaviour (Gulbicka, 2014). The promotion of Polish food is handled by many state institutions as well as industry organizations, foundations and associations including the Institute for Market, Consumption and Economic Research, Polish Agency for Enterprise Development, and the Polish Chamber of Commerce.

In recent years, managers managing petrol station chains have also become interested in regional food products. It turned out that food products, especially those produced locally, could become one of the distinguishing features of a petrol station, as well as a source of marketing innovations welcomed by the station's customers. Regional food products may also positively affect the competitive position of the petrol station, and the regional products offer may become one of the areas of competition for petrol stations. The next part of the article will present the results of own research regarding the use of marketing innovations on the petrol stations and the assessment and willingness to purchase local food products by the petrol stations customers.

\section{Marketing innovations as a type of innovation}

Marketing innovations have been the subject of research and analysis for many years. Still, it arouses great interest of researchers and management practitioners. This, among other things, is due to the fact that innovative solutions have a limited lifetime and over time they become a kind of standard for a given industry or other group of entities. On the other hand, innovations are a necessity, an indispensable element for success in the current environment. By many researchers, the subject is considered a source of competitive advantage. Due to the pace of changes along with the development of technology, the approach to the subject of innovation is modified, which applies not only to enterprises, but also to other organizations, such as universities, local governments and non-profit organizations. The concept of innovation is found in many different fields and disciplines, such as management sciences, psychology, economics, sociology, etc. Therefore, there is no single, universal definition of innovation. What is more, this concept evolves over time, and new paradigms and criteria for the division of innovations arise. Marketing innovations deserve special attention due to, among other things, changing customer roles in the process of creating innovations or changes in the scope of shopping preferences. 
Researchers on the subject of innovation consider that the precursor is Joseph A. Schumpeter, the Austrian economist, who linked innovation to the causes of economic development, figuratively depicting it as "disrupting the balance that permanently modifies and precipitates the previously existing state of equilibrium from the former bearing" (Schumpeter, 1960 , p. 101). Such a mechanistic understanding of innovation should be linked to the period in which the scholar lived - the industrial era. It should be emphasized that the concept of innovation was used for the first time in 1911 (date of publication of J. Schumpeter's dissertation). J. Schumpeter's theories are often referred to as creative destruction because current knowledge loses its importance and new competences are needed to compete effectively (Śmigielska and Wiśniewska, 2016, p. 58). J. Schumpeter related the concept of innovation to five dimensions:

- A new commodity or a new species of goods previously unknown to consumers;

- Introduction of a new production method;

- Opening of a new market;

- Acquisition of a new source of raw materials, semi-finished products;

- Creation of a new industry organization, e.g. a monopoly (Kozioł-Nadolna, 2012, pp. 295-296).

J. Schumpeter, despite the fact that he was referring only to the productive aspects of innovation, made a significant impact in the development of the 20th century management sciences. In understanding innovation, the organizational and marketing aspect was also noticed with time, mainly due to the significant development of services in the eighties and nineties of the twentieth century. The views of Peter Drucker had a significant impact on the practice of business operations and the theory of management. He proposed a different perception of innovation as a process of a social and economic nature, not directly related to economic phenomena (Jasiulewicz and Waśkowski, 2015, p. 101) or technical issues. According to P. Drucker, "innovation is a sequence of events that allows the entrepreneur to gain a competitive advantage" (1992, pp. 43-44). In the same period, the evolution of innovation concepts was described by Roy Rothwell (1992, pp. 221-239), in which five models can be distinguished.

It is worth emphasizing that over the years the concept of innovation has evolved significantly - from the productive perception of innovation in J. A. Schumpeter's theory to the concept of open innovation. In the first period, the role of technology as the leading source of innovation was emphasized. In the mid-fifties and sixties of the twentieth century, more attention was paid to demand, which influenced the development of marketing and quality management. In the 1980s, innovations began to be considered in both the supply and demand aspects - they were defined as skilful perception of market needs and their confrontation with the technical and production capabilities of the enterprise (Zupok, 2015, pp. 43-44). Michael Porter, known mainly from the so-called model of "five Porter forces" shaping the company's micro-innovation, also contributed to the development of innovation. According to him, 
innovation is "economically successful exploitation of ideas" in terms of both new products and processes, as well as smaller modifications that are new to the introducing entity (2001, p. 23).

Among contemporary approaches to innovation, one should mention C.K. Prahalad and M. Kishnan, who in their definition of innovation refer to customers, their expectations and permanent response of a company to these expectations. This definition has been formulated as follows: "shaping consumer expectations and continuously responding to their changing requirements, behaviours and experiences" (2012, p. 12). The topic of innovation is also addressed by Polish researchers. S. Gomułka uses the concept of "act of qualitative change in the economy" (1998, pp. 17-20), W. Grudzewski and I. Hejduk write about a new "thought, qualitatively different from existing ones" (2000, pp. 138-140). Whereas S. Marciniak mentions "creative changes in the social system, economic structure, technology and nature" (2000, pp. 11-18). A. Pomykalski defines innovation as "all research and development processes aimed at the application and use of improved solutions in the field of technology and organization" (2001, p. 17). A slightly different approach to innovation, not strictly related to manufacturing activity, is also presented by A. Pomykalski, defining innovation as "an activity aimed at adding added value for shareholders, consumers and other interest groups" (2001, p. 9). The broad definition of innovation, including the social aspect, is provided by L. Białon in his works: innovation is the introduction of changes to economic and social systems, which result in the increase of usability of products/services, technological processes and management systems, improvement of rationality of management, protection and improvement of the natural environment, better communication between people and ultimately improvement of the quality of professional life and private life of society (2010, p. 19).

In addition to the already mentioned scientists, the subject of innovation is also dealt with, among others, by: B. Reformat, P. Niedzielski, J. Chwałek, J. Baruk, M. Sławińska, B. Kucharska, B. Borusiak, I. P. Rutkowski. Analysing the literature on innovation, domestic and foreign, it should be noted that most authors cite the definitions created by the European Union for the needs of economic practice in the so-called Oslo Manual (Oslo Manual). This is one of the best-known documents dealing with innovations, and the methodology contained therein "forms the basis for statistical surveys [...] of innovations constituting the current main source of information on information activities in European countries" (Reformat, 2015, p. 24). According to the Oslo Manual, innovation means "implementing a new or significantly improved product (product or service) or process, a new marketing method or a new organizational method in business practice, workplace organization or relations with the environment" (2008, p. 45). This definition allows treating any novelty as an innovation if it is new to its user (Źelichowska, 2009, p. 50). The document also introduces a typology of innovations that is applicable in all areas of the economy, including retail. The classification in the Oslo Manual (2008, p. 45) distinguishes the following innovations: 
- product and service

- process

- marketing

- organizational.

It should be emphasized that in many cases a given innovation can be classified as a productservice innovation as well as a process innovation. This situation results from the fact that advanced product and service innovations require changes in the production or distribution process.

Marketing innovations have been defined in the literature in a narrow and broad sense. The broad definition of marketing innovations encompasses all aspects of new activities aimed at better adjustment of the product to the current needs of clients (Śmigielska and Wiśniewska, 2016, p. 59). The authors are closer to the definition of marketing innovations proposed by B. Reformat, who understands them as those "related to the product, offered prices, distribution and sales (including customer service and their support, e.g. lending) and promotion and market communication" (Reformat, 2017, p. 21). Marketing innovations in a broad sense are the innovations aimed not only at adapting the product itself to the current needs reported by customers, but above all finding a new way of offering a given good or service. The authors of this paper, bearing in mind the above broad definition of marketing innovations, propose the division of marketing innovations (fig. 1) into the following subgroups regarding:

- product and its exposure,

- prices and loyalty,

- distribution,

- promotions and methods of communication,

- other, where one can qualify to innovations that go beyond their usual way of understanding.

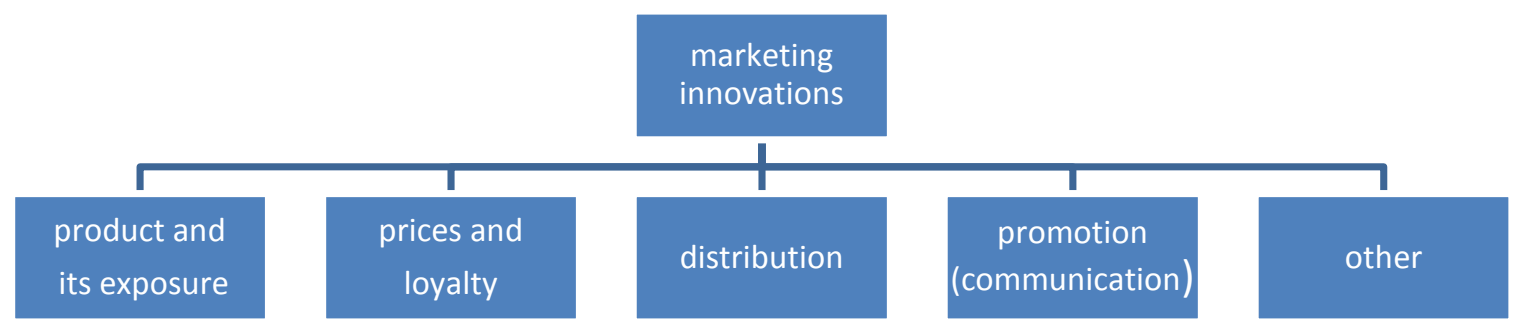

Figure 1. Marketing innovation - division into subcategories. Source: Own elaboration. 


\section{Petrol stations sector in Poland}

The petrol station sector in Poland consists of about 7021 facilities (as at 30.06.2018), which is presented in table 1. The leader in terms of the number (in brackets) of petrol stations in Poland is PKN Orlen (1834), followed by Lotos (683), BP (537), Shell (420) and CircleK (348). Petrol stations run by retail chains (like Auchan, Carrefour, Tesco) play a very important marketing role - to attract customers to shopping centres (offering significantly lower prices). The estimated number of independent petrol stations is 4108 facilities. They play an important role due to the big number of facilities.

Table 1.

Estimated number of petrol stations in Poland, by key operators (as at 30.06.2018)

\begin{tabular}{|c|c|c|c|}
\hline Operator & $\begin{array}{c}\text { Number of } \\
\text { petrol stations }\end{array}$ & $\begin{array}{l}\text { Average growth rate } \\
\text { for } 2015-2017 \\
(\text { expressed in } \%)\end{array}$ & $\begin{array}{c}\text { Percentage share } \\
\text { (number of stations } \\
\text { of a given operator / } \\
\text { number of petrol } \\
\text { stations in total) }\end{array}$ \\
\hline $\begin{array}{l}\text { PKN ORLEN } \\
\text { including brand BLISKA }\end{array}$ & $\begin{array}{c}1,771 \\
63\end{array}$ & $\begin{array}{c}100.15 \\
69.65\end{array}$ & 25.22 \\
\hline $\mathrm{BP}$ & 537 & 103.81 & 7.65 \\
\hline $\begin{array}{l}\text { LOTOS GROUP } \\
\text { including brand OPTIMA }\end{array}$ & $\begin{array}{l}484 \\
199 \\
\end{array}$ & $\begin{array}{l}103.83 \\
106.82 \\
\end{array}$ & 6.89 \\
\hline SHELL & 420 & 101.75 & 5.98 \\
\hline CircleK & 348 & 99.82 & 4.96 \\
\hline $\begin{array}{l}\text { Petrol stations owned by the retail } \\
\text { chains (like Auchan, Carrefour, Tesco) }\end{array}$ & 190 & 103.03 & 2.71 \\
\hline AMIC & 115 & 99.71 & 1.64 \\
\hline TOTAL & 29 & 267.92 & 0.41 \\
\hline AS24 & 28 & 101.33 & 0.40 \\
\hline IDS & 14 & 118.52 & 0.20 \\
\hline $\begin{array}{l}\text { Independent petrol stations including } \\
\text { MOYA and stations in operator } \\
\text { networks with a common } \log _{0} *\end{array}$ & $\begin{array}{l}3,085 \\
1,023\end{array}$ & $\begin{array}{l}100.14 \\
107.89\end{array}$ & 43.94 \\
\hline Total petrol stations & 7,021 & 100.83 & 100 \\
\hline
\end{tabular}

Legend: * - common name, different owner.

Source: (POPiHN, 2018c, p. 1).

It is worth noting that petrol stations are disproportionately spread across the country. The highest density coefficient occurs in the Śląskie Voivodeship ( 85 facilities per $1,000 \mathrm{~km}^{2}$ ) and the lowest in Podlasie and Warmisko-Mazurski voivodeship (13 facilities per 1,000 $\mathrm{km}^{2}$ ) (GUS, 2016). Petrol sold at stations is a relatively low-margin product, hence dynamic changes in the range of petrol stations. Increasingly, the petrol station customer can benefit from services that were previously reserved for other commercial units, such as sending and receiving courier parcels, selling motor insurance, or renting cars. On one hand, the maximization of customer satisfaction and the induction of positive brand perception by customers of a given network underlies these activities, but on the other hand the reason are the relatively low margins on the petrol sold (Suszyńska, Zawadzki 2017, p. 23). An example which well illustrates the situation 
is the margin obtained from the sale of petrol and coffee. Selling petrol for PLN 100 (most typical purchase) the station's owner gains only PLN 1.47 margin, and from the sale of one coffee for PLN 7.99 the station gets PLN 4.39 margin. This explains to a large extent why the offer of goods and services offered by petrol stations has grown so much in recent years. The station earns primarily on the sale of goods (not on petrol, which is a magnet, but not a profit centre). An interesting category introduced in recent years to the offer of petrol stations are traditional and regional products, which can be perceived as one of the ways to distinguish and increase the competitive advantage of petrol stations. These aspects will be presented in the next part of the article.

\section{Regional food products at petrol stations - Wielkopolska Region example}

The co-author of this paper is a member of an international project entitled "FoodBiz University and business learning for new employability paths in food and gastronomy". FoodBiz is an international project aimed at integrating the academic community with enterprises from the food sector including local farmers, restaurateurs and food producers. As part of the project, a workshop was organized in Poznan on 26.06.2018, the aim of which was to diagnose the needs of local entrepreneurs. There were local representatives from Wielkopolska including FMCG producers (e.g. Xawery Miodowy, Chias), food producers (e.g. Grodzki cheese, Inna Piekarnia, Gryszczeniówka) and law-making representatives among the invited guests. Two conclusions were convergent with the subject of the article:

- There are no characteristic products for Wielkopolska. This situation is perceived by food producers sector representation both as a negative phenomenon (lack of unambiguous recognition of the region as in the case, for example, of Oscypek cheese and the Podhale region), and an opportunity to use a kind of carte blanche to promote the product.

- There are too many unreliable certifications, markings and contests to guarantee the quality and regional character of a given product. The food producers gathered during the workshop indicate the need to create one official certificate confirming the regional character of a product. Ideally, a reliable certificate should be issued only by a local government unit as a solution.

In order to verify how products originating from Wielkopolska 'compare' to regional products from other regions of Poland, comparison was carried out using the "Wielkopolska and the rest of the country" method. It is based on the list of traditional products published by The Ministry of Agriculture and Rural Development in Poland and on the basis of other accredited related titles such as "Quality and tradition". 
The following two institutions providing the marking were chosen mainly due to the authenticity of the publication body. The List of Traditional Products, published by the Ministry of Agriculture and Rural Development, is an example of the implementation of the Quality Policy in the Community (https://www.gov.pl/rolnictwo/produkty-regionalne-itradycyjne1). It is a list of products whose quality or unique features and properties result from the use of traditional production methods. It was created under the Act of 17 December 2004 on the registration and protection of names and designations of agricultural products and foodstuffs and on traditional products (methods used for at least 25 years are considered traditional). Table 2 presents a summary of products entered into the list, broken down by individual voivodeships. Wielkopolska is on eighth place in the regional ranking in terms of the number of products entered into the List of Traditional Products - there are 93 products. An additional column with the size of the voivodeship in $\mathrm{km}^{2}$ is attached in table 2 . The presented data show that Wielkopolska is located in the middle of the voivodeship table and the number of entered products is not directly proportional to the area of voivodeship. In addition, table 3 presents the breakdown of products originating from Wielkopolska by categories. The most numerous category of products are fresh meat and meat products (e.g. Rokietnicka Juniper sausage), ready meals and dishes (czernina), beverages (alcoholic and non-alcoholic, e.g. beer from Bojanowo).

Table 2.

The list of traditional products in voivodeships in Poland

\begin{tabular}{|l|l|c|c|}
\hline No & \multicolumn{1}{|c|}{ Voivodeship } & $\begin{array}{c}\text { The number of products } \\
\text { included in the list of } \\
\text { traditional products - in total }\end{array}$ & $\begin{array}{c}\text { The area of the voivodeship } \\
\text { in km } \mathbf{~}^{2}\end{array}$ \\
\hline 1 & Podkarpackie & 227 & 17,846 \\
\hline 2 & Lubelskie & 204 & 13,988 \\
\hline 3 & Pomorskie & 178 & 18,310 \\
\hline 4 & Śląskie & 145 & 12,333 \\
\hline 5 & Lódzkie & 135 & 18,219 \\
\hline 6 & Mazowieckie & 128 & 35,558 \\
\hline 7 & Małopolskie & 128 & 15,183 \\
\hline 8 & Wielkopolskie & 93 & 29,826 \\
\hline 9 & Swiętokrzyskie & 92 & 11,710 \\
\hline 10 & Kujawsko-pomorskie & 81 & 17,971 \\
\hline 11 & Lubelskie & 73 & 25,122 \\
\hline 12 & Podlaskie & 66 & 20,187 \\
\hline 13 & Opolskie & 62 & 9,411 \\
\hline 14 & Warmińsko-mazurskie & 32 & 24,173 \\
\hline 14 & Zachodniopomorskie & 49 & 22,892 \\
\hline 15 & Dolnośląskie & 49 & 19,947 \\
\hline
\end{tabular}

Source: own study based on BGŻ BNP PARIBAS report and GUS.

Another notable system of regional food marking is Jakość Tradycja (Quality Tradition) system, which by the decision of the Minister of Agriculture and Rural Development from June 2007 is considered to be a national food quality system (www.produktyregionalne.pl/ jakosc.html). 
Table 3.

Products originating from Wielkopolska by categories

\begin{tabular}{|c|l|c|}
\hline Voivodeship & \multicolumn{1}{|c|}{ Products categories } & $\begin{array}{c}\text { The number of products in the } \\
\text { list of traditional products }\end{array}$ \\
\hline \multirow{5}{*}{ Wielkopolskie } & Fresh meat and meat products & 33 \\
\cline { 2 - 3 } & Ready meals and dishes & 20 \\
\cline { 2 - 3 } & Beverages (alcoholic and non-alcoholic) & 10 \\
\cline { 2 - 3 } & Nuts, seeds, cereals, vegetables and fruits & 7 \\
\cline { 2 - 3 } & Bakery and confectionery & 6 \\
\cline { 2 - 3 } & Oils and fats (butter, margarine, etc.) & 6 \\
\cline { 2 - 3 } & Cheese and other dairy products & 6 \\
\cline { 2 - 3 } & Honey & 2 \\
\cline { 2 - 3 } & Fishery products, including fish & 1 \\
\cline { 2 - 3 } & Other products & 2 \\
\hline
\end{tabular}

Source: own study based on BGŻ BNP PARIBAS report.

This system is used to distinguish high-quality food products, including traditional products, and consists of three pillars - three product marking systems: Protected Designation of Origin, Protected Geographical Indication, and Guaranteed Traditional Specialty. Products with the Protected Designation of Origin mark are of outstanding quality directly related to the area in which they are produced. This marking is awarded by the European Commission. The domain of such products is the fact that all raw materials come from a given geographical area, all production takes place within one area, and the quality of the products exceeds the remaining products in the category. At present, 9 products are registered; however, there is no product from Wielkopolska. Table 4 contains a list of products with the Protected Designation of Origin mark.

Table 4.

List of products with the Protected Designation of Origin mark

\begin{tabular}{|l|l|l|}
\hline No & \multicolumn{1}{|c|}{ Product } & \multicolumn{1}{c|}{ Voivodeship } \\
\hline 1 & Bryndza podhalańska (cheese) & Małopolskie \\
\hline 2 & Oscypek (cheese) & Małopolskie \\
\hline 3 & Redykołka (cheese) & Małopolskie \\
\hline 4 & Wiśnia nadwiślańska (cherry) & Swiętokrzyskie and Mazowieckie \\
\hline 5 & Podkarpacki Miód Spadziowy (honey) & Podkarpackie \\
\hline 6 & Miód z Sejneńszczyzny/Łoździej (honey) & Podlaskie \\
\hline 7 & Fasola wrzawska (beans) & Podkarpackie \\
\hline 8 & Fasola „Piękny Jaś” z Doliny Dunajca (beans) & Małopolskie \\
\hline 9 & Karp zatorski (carp) & Małopolskie \\
\hline
\end{tabular}

Source: own study based on 'Quality Tradition' list.

The second designation under the title 'Quality Tradition' is the Protected Geographical Indication marking, which is awarded to products whose at least one production stage takes place in the defined geographical area. Currently, 18 Polish products are registered, including two from Wielkopolska. Table 5 contains a list of products bearing the Protected Geographical Indication marking. 
Table 5.

List of products with the Protected Geographical Indication mark

\begin{tabular}{|l|l|l|}
\hline No & \multicolumn{1}{|c|}{ Product } & \multicolumn{1}{|c|}{ Voivodeship } \\
\hline 0 & Cebularz lubelski (bake) & Lubelskie \\
\hline 1 & Wielkopolski smażony (fried cheese) & Wielkopolskie \\
\hline 2 & koryciński swojski(homemade) & Podlaskie \\
\hline 3 & Kiełbasa lisiecka (sausage) & Małopolskie \\
\hline 4 & Miód wrzosowy z Borów Dolnośląskich (heatherhoney) & Dolnośląskie \\
\hline 5 & Miód drahimski (honey) & Zachodniopomorskie \\
\hline 6 & Miód kurpiowski (honey) & Mazowieckie \\
\hline 7 & Andruty kaliskie (wafers) & Wielkopolskie \\
\hline 8 & Rogal świętomarciński(croissant) & Wielkopolskie \\
\hline 9 & Kołocz śląski (cake) & Opolskie, Śląskie \\
\hline 10 & Chleb prądnicki (bread) & Małopolskie \\
\hline 11 & Obwarzanek krakowski (bagel) & Małopolskie \\
\hline 12 & Truskawka kaszubska (strawberry) & Pomorskie \\
\hline 13 & Jabłka grójeckie (apples) & Mazowieckie \\
\hline 14 & Jabłka łąckie (apples) & Małopolskie \\
\hline 15 & Suska sechlońska (plum) & Małopolskie \\
\hline 16 & Śliwka szydłowska (plum) & Świętokrzyskie \\
\hline 17 & Fasola korczyńska (beans) & Śiętokrzyskie \\
\hline 18 & Jagnięcina podhalańska (lamb) & Małopolskie and Śląskie \\
\hline
\end{tabular}

Source: own study based on 'Quality Tradition' list.

The third designation awarded by the "Quality Tradition" is the Traditional Specialty Guaranteed mark. The products so marked are made from a specific raw material, they are distinguished from the competition and their traditional character results from the use of traditional raw materials, recipe or technology. According to the regulation of the European Parliament and the EU Council (1151/2012), a "traditional" product should have at least 30 years of proven history and market presence. Table 6 contains a list of products with the Traditional Specialty Guaranteed mark.

Table 6.

List of products with the Traditional Specialty Guaranteed mark

\begin{tabular}{|l|l|l|}
\hline No & Product & \multicolumn{1}{c|}{ Production region } \\
\hline 1 & Pierekaczewnik (bake) & Podlaskie Voivodeship \\
\hline 2 & Meads: półtorak, dwójniak, trójniak and czwórniak & Whole Poland \\
\hline 3 & Kabanosy (sausage) & Whole Poland \\
\hline 4 & Kiełbasa jałowcowa (Juniper sausage) & Whole Poland \\
\hline 5 & Kiełbasa myśliwska (Hunter sausage) & Whole Poland \\
\hline 6 & Olej rydzowy (Grain oil) & Wielkopolskie Voivodeship \\
\hline
\end{tabular}

Source: own study based on 'Quality Tradition' list.

Summarizing the above statements, products from the Wielkopolska region can be found both on the list of traditional products and on the list of products marked with Protected Geographical Indication and Traditional Specialty Guaranteed mark. 
The authors of this article carried out market research in order to look at the subject of regional products from the perspective of demand. In June 2018 shopping preferences of Poles were examined. The study was carried out using the CAWI internet interview technique on a nationwide representative sample of adult $\operatorname{Poles}^{1}(\mathrm{~N}=603)$. Research shows that almost $60 \%$ of respondents eagerly buy regional products regardless of the format of the store $(15 \%$ of responses were definitely yes, $44 \%$ were probably yes). The distribution of responses is presented in Table 7.

Table 7.

Purchase of regional products - general overview.

\begin{tabular}{|l|c|}
\hline \multicolumn{2}{|l|}{$\begin{array}{l}\text { Do you buy regional products (e.g. juices from regional producers, local craft beers, healthy snacks) } \\
\text { regardless of the type of place of purchase? }\end{array}$} \\
\hline Answer & Response (in \%) \\
\hline Definitely yes & 15 \\
\hline Probably yes & 44 \\
\hline Difficult to state & 18 \\
\hline Probably no & 21 \\
\hline Definitely no & 2 \\
\hline
\end{tabular}

Source: own study based on the conducted research.

While answering the question about purchasing regional products, $15 \%$ of the respondents answered "definitely yes", while 44\% answered "probably yes", which in total gives Top2Boxes results at 59\%. As a result of the nature of the article and the author's scientific interest during the study in question, they were also asked about the purchase of regional products at petrol stations. Table 8 contains a summary of the response to the question: Would you buy regional products if they were available at petrol stations (e.g. juices from regional producers, local craft beers, healthy snacks)? The study shows that $55 \%$ of respondents would be definitely happy to buy regional products at petrol stations (Top2Boxes results).

Table 8.

Purchase of regional products at petrol stations - research study

\begin{tabular}{|l|c|}
\hline $\begin{array}{l}\text { Would you buy regional products if they were available at petrol stations (e.g. juices from regional } \\
\text { producers, local craft beers, healthy snacks)? }\end{array}$ \\
\hline Response & Response (in \%) \\
\hline Definitely yes & 15 \\
\hline Probably yes & 40 \\
\hline Difficult to state & 31 \\
\hline Rather no & 12 \\
\hline Definitely no & 2 \\
\hline
\end{tabular}

Source: own study based on the results of the research.

It is the PKN ORLEN network that currently focuses the most on regional products. PKN ORLEN has special shelves marked as "Spiżarnia Regionów" ("Regional pantry"), at selected petrol stations where food products from regional suppliers (mainly food and craft beer) are highly promoted. There are more than 70 regional products available for customers,

\footnotetext{
1 The shares for the following characteristics of respondents were checked: gender, age, place of residence, in order to ensure the representativeness of the sample during the implementation. $\mathrm{N}=603$.
} 
from 23 Polish farmers and entrepreneurs, in 4 provinces (www.orlen.pl). Such offer should be considered as a response to the current customer purchase needs. Currently at 590 stations products made by local producers are available: regional beer, juices and beverages from Polish fruit, honey, local pastries, and snacks. Products that are part of the interest in traditional, often original recipes from Polish producers are promoted. The project is implemented in cooperation with the Ministry of Agriculture and Rural Development and the Agricultural Market Agency. Within the stores special shelves have been designated and special stands have been created, namely furnishing referring to traditional decor at the facilities with a larger store area. In addition, the purchase of products in the discussed offer is additionally rewarded in the Orlen loyalty program. Figure 2 shows an exemplary stand located at a petrol station in Tulce (Wielkopolska) and Table 9 shows product specification.

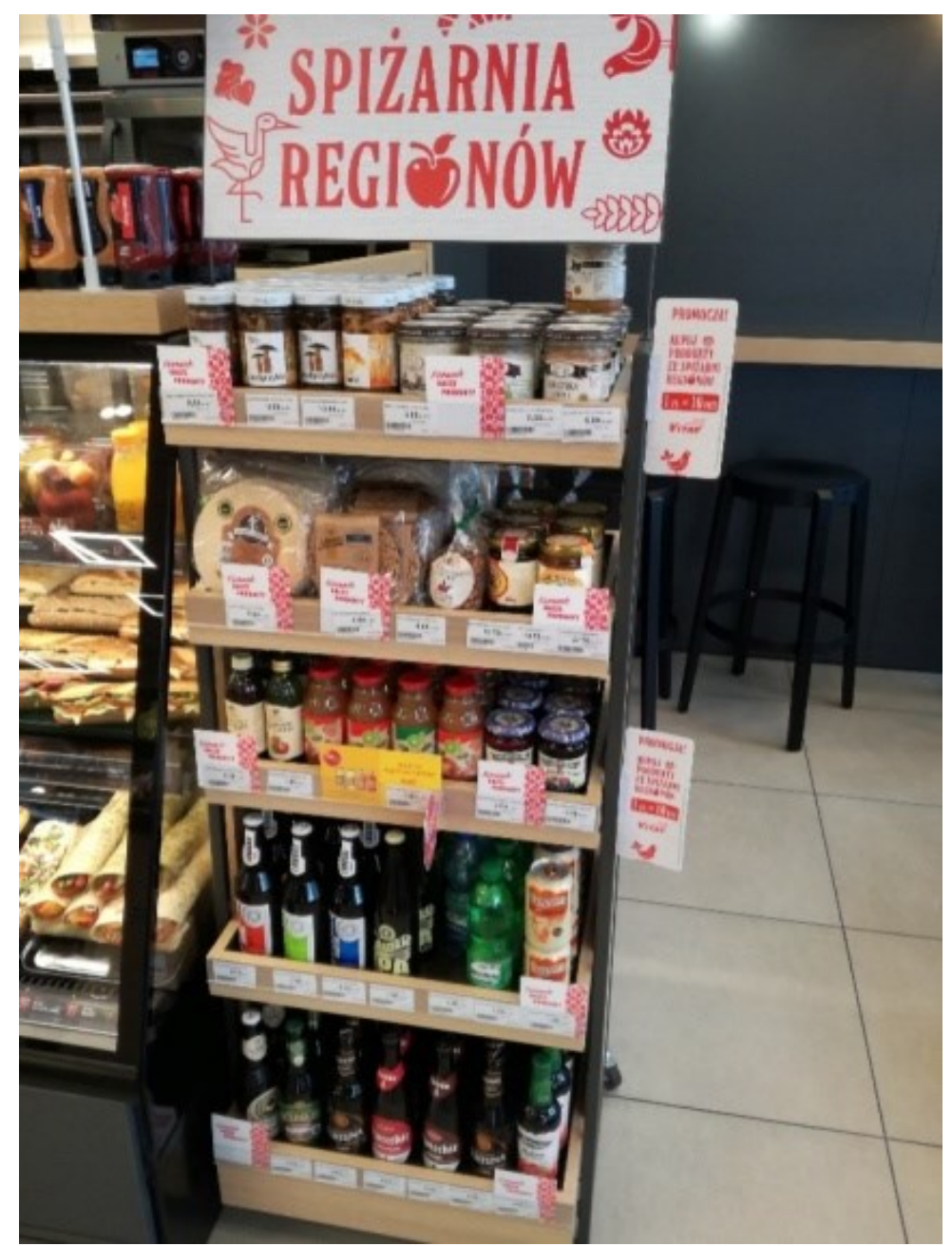

Figure 2. A glimpse at the "Regional pantry". Source: author's own work.

The "Spiżarnia Regionów" project was launched as a pilot project in September 2017 and was warmly welcomed by customers. The number of outlets with the offer being discussed increased and it is planned to introduce it to other facilities. 
Table 9.

List of products, at the Spizarnia Regionów (Regional Pantry) stand

\begin{tabular}{|l|l|l|}
\hline \multicolumn{1}{|c|}{ No } & \multicolumn{1}{|c|}{ Product } & \multicolumn{1}{c|}{ Category } \\
\hline 1 & Mushrooms in jars & Preserves \\
\hline 2 & Meat in jars & Meat \\
\hline 3 & Wafers & Confectionary \\
\hline 4 & Cupcake with seeds & Confectionary \\
\hline 5 & Oatmeal cookies & Confectionary \\
\hline 6 & Bee honey & Honey \\
\hline 7 & Pressed juice & Drinks and juices \\
\hline 8 & Pressed juice - O! own jams & Drinks and juices \\
\hline 9 & Jam & Preserves \\
\hline 10 & Craft beer & Drinks and juices \\
\hline 11 & Highly mineralized water & Drinks and juices \\
\hline 12 & Orangeade & Drinks and juices \\
\hline 13 & Craft beer & Drinks and juices \\
\hline 14 & Juice - concentrate & Drinks and juices \\
\hline
\end{tabular}

Source: own study.

PKN Orlen press releases and the growing number of petrol stations with the "Spiżarnia Regionów" offer confirm that this project will be expanded within the group. Another example of a petrol station network that has introduced regional products into its facilities is the Citronex network (petrol station facilities are located in South West Poland). Customers can buy, among others, fresh tomatoes (and whole crates), bananas or cold pressed juices from local suppliers at the Citronex gas stations. The solutions used by PKN Orlen, as a leader in terms of the number of petrol stations and as the owner of a valued brand, are being emulated by other petrol station networks. In the near future, the "Spiżarnia Regionów" solution will also be implemented in other petrol station networks. Benchmarking, a practice used in management consisting in comparing and implementing best practices from competing enterprises, is mentioned as one of the main sources of innovation among companies in the petrol station sector.

\section{Conclusions}

The research shows that Poles are eager to buy regional products and look for them in places where they have never been available before (petrol stations). Both research results and the development of the "Spiżarnia Regionów" concept show that petrol stations will be an important sales channel for regional products. The pilot program "Spiżarnia Regionów" at Orlen petrol stations proved to be a success, and regional products are more and more widely available at the petrol stations of the Polish concern. Considering the specificity of the sector and benchmarking as a method for changing the offer, it can be assumed that the remaining operators of the station network will introduce regional products to the offer shortly as the regional goods are being chosen and desired increasingly by customers of petrol stations in Poland. 


\section{References}

1. Białoń, L. (2010). Zręby teorii innowacji. In: L. Białoń (ed.), Zarządzanie działalnościa innowacyjna (p. 11-60). Warszawa: Placet.

2. Drucker, P. (1992). Innowacja i przedsiębiorczość. Polityka i zasady. Warszawa: PWE.

3. Gas stations in Poland 2010-2018 - Q1 2018 report, POPiHN.

4. Gomułka, S. (1998). Teoria innowacji i wzrostu gospodarczego. Warszawa: CASE.

5. Gulbicka, B. (2014). Żywność tradycyjna i regionalna w Polsce. Warszawa: IERiGR.

6. http://promocjazywnosci.pl/rozdzial_2_4.html.

7. https://www.gov.pl/rolnictwo/produkty-regionalne-i-tradycyjne1.

8. Jasiulewicz, A., Waśkowski, Z. (2015). Innowacje marketingowe jako źródło przewagi konkurencyjnej uczelni wyższych. Marketing Instytucji Naukowych i Badawczych, 4(18), 98-114.

9. Kozioł-Nadolna, K. (2012). Modele zarządzania innowacjami w XXI wieku. In: B. Mikuła, (ed.), Historia i perspektywy nauk o zarządzaniu (p. 295-302). Kraków: Wydawnictwo Uniwersytetu Ekonomicznego.

10. Marciniak, S. (2000). Innowacje i rozwój gospodarczy. Warszawa: Kolegium Nauk Społecznych i Administracji Politechniki Warszawskiej.

11. Podręcznik Oslo. Zasady gromadzenia i interpretacji danych dotyczacych innowacji. Wydanie trzecie (2008), Paryż: OECD i Eurostat.

12. Pomykalski, A. (2001). Zarządzanie innowacjami. Warszawa-Łódź: PWN.

13. Porter, M.E. (2001). Porter o konkurencji. Warszawa: PWN.

14. Prahalad, C.K., Krishnan, S.M. (2012). Nowa era innowacji. Warszawa: PWN.

15. Reformat, B. (2015). Innowacje w budowaniu przewagi konkurencyjnej organizacji handlu detalicznego. Katowice: Wydawnictwo Uniwersytetu Ekonomicznego.

16. Rocznik Statystyczny (2018). Warszawa: GUS.

17. Rothwell, R. (1992). Successful Industrial Innovation: Critical Success Factors for the 1990. R\&D Management.

18. Schumpeter, J.A. (1960). Teoria rozwoju gospodarczego. Warszawa: PWN.

19. Suszyńska K., Zawadzki, T. (2017). Formy zarządzania stacjami paliw w Polsce. Przegląd Nauk Stosowanych, nr 14. Opole: Politechnika Opolska.

20. Śmigielska, G., Wiśniewska, S. (2016). Innowacje marketingowe w handlu detalicznym. Problemy Zarządzania, 14(1), 57-70.

21. Wyciszkiewicz, P., Zawadzki, T. (2018). Satysfakcja klientów obiektów handlowych na przykładzie stacji paliw - raport z badań. Problemy Rynku Nieruchomości, Poznań: SRMWW. 
22. Zupok, S. (2015). Wpływ innowacji na kreowanie wartości dla klienta. Studia i Prace Wydziału Nauk Ekonomicznych i Zarzadzania, 39, tom 2.

23. Żelichowska, M. (2009). Innowacyjność jako determinanta konkurencyjności przedsiębiorstw. Zeszyty Naukowe Wyższej Szkoły Humanitas. Zarządzanie, nr 1. 